\title{
The Effect of Aeration for 6-Pentyl-alpha-pyrone, Conidia and Lytic Enzymes Production by Trichoderma asperellum Strains Grown in Solid-State Fermentation
}

\author{
Rayhane Hamrouni ${ }^{1,3} \cdot$ Josiane Molinet $^{1} \cdot$ Nathalie Dupuy $^{1} \cdot$ Nadira Taieb $^{1} \cdot$ Quentin Carboue $^{1} \cdot$ Ahmed Masmoudi $^{2}$. \\ Sevastianos Roussos ${ }^{1}$
}

Received: 16 April 2019 / Accepted: 4 September 2019 / Published online: 3 October 2019

(c) The Author(s) 2019

\begin{abstract}
In recent years, the production of biopesticides has gained great attention in the scientific word because it is an important alternative to replace the much debated chemical pesticides used on the field crops. Fungal lytic enzymes, conidia and secondary metabolites like 6 pentyl-alpha-pyrone (6-PP) play a very important role in the biological control of pests. On the present study, the influence of application of air through a solid-state fermentation using three Trichoderma asperellum strains to produce conidia, 6-PP and essential enzymes were evaluated. A mix of vine shoots, potatoes flour, jatropha, olive pomace and olive oil as substrates was used. T. asperellum TV104 showed the best 6-PP production $\left(3.06 \pm 0.15 \mathrm{mg} \mathrm{g} \mathrm{DM}^{-1}\right)$, cellulases activities $\left(34.3 \pm 0.4 \mathrm{U} \mathrm{g}^{-1}\right)$, and amylase activity $\left(46.3 \pm 0.6 \mathrm{U} \mathrm{g}^{-1}\right)$ however, $T$. asperellum $\mathrm{TF} 1$ produced the higher levels of lipase $\left(30.6 \pm 0.3 \mathrm{U} \mathrm{g}^{-1}\right)$, under air conditions. The production of these same enzymes was less efficient without the application of forced aeration. The forced aeration increased the conidia production, the best value was observed with T. asperellum $\mathrm{TF} 1\left(2.23 \pm 0.07 \times 10^{9} \mathrm{~g} \mathrm{DM}^{-1}\right)$.
\end{abstract}

\section{Graphic Abstract}

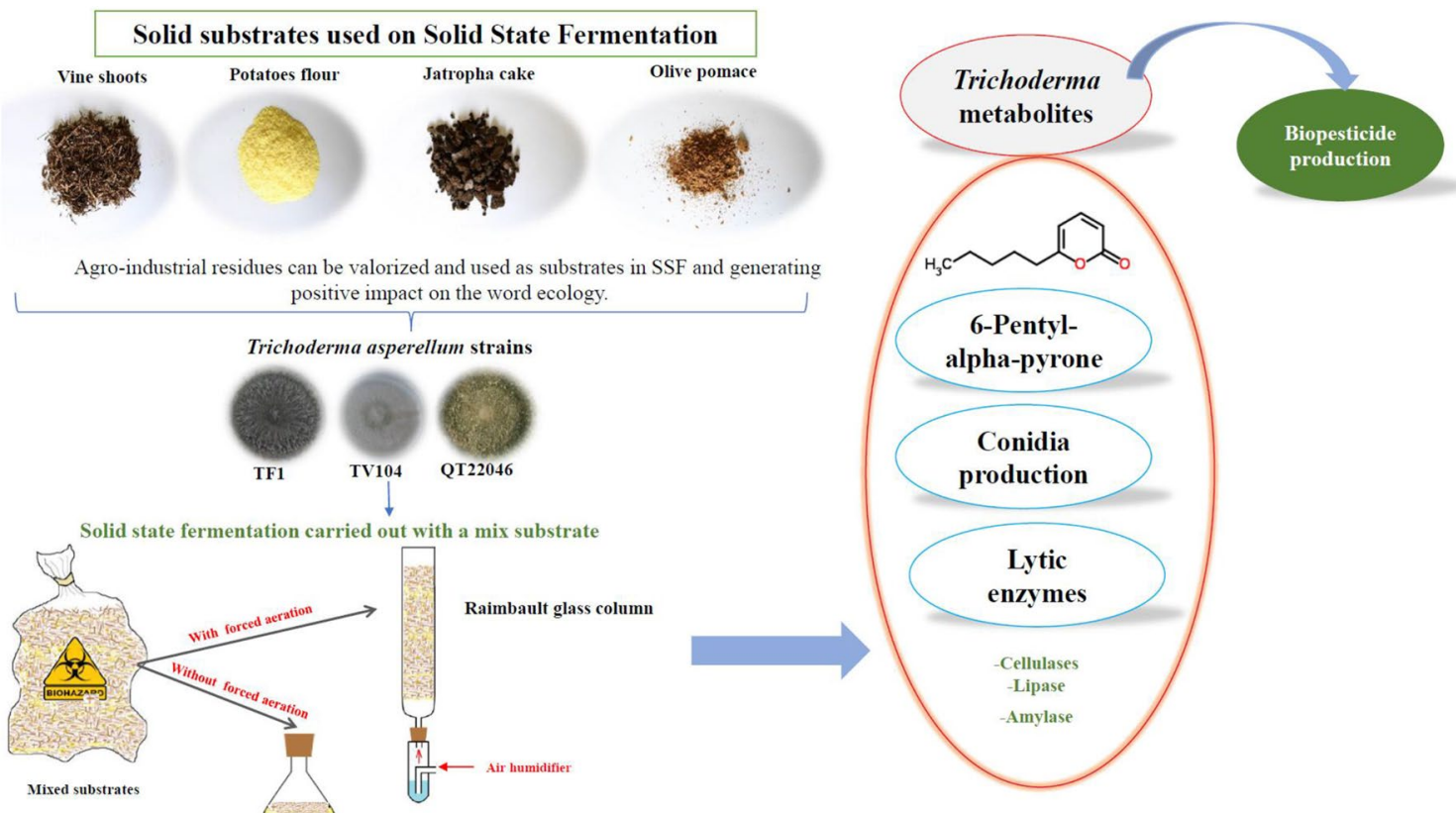

Keywords Trichoderma asperellum $\cdot$ Biological control $\cdot$ Solid-state fermentation $\cdot$ Enzymes $\cdot$ 6-Pentyl-alpha-pyrone

Extended author information available on the last page of the article 


\section{Statement of Novelty}

Trichoderma is a filamentous fungus considered a biocontrol agent, it has been a very important model for study because of its mechanisms of action; nutrients and space competence, antibiotics production and lytic enzymes production. Solid state fermentation allows the valorization of agroindustrial wastes having an impact on the worldwide ecology. This production system has the potential to produce value-added products such as antibiotics, pigments, aromas and enzymes of industrial interest like cellulases, chitinases, amylases, etc., On the present study, the application of forced aeration through a solid-state fermentation using three Trichoderma asperellum strains is evaluated to produce 6-PP, conidia and essential enzymes. A mix of agroindustrial byproducts like vine shoots, jatropha, potatoes flour, olive pomace and olive oil is used as substrate, which offer economic advantages in the fermentation process.

\section{Introduction}

In recent years, biopesticides are recognized as a viable alternative to control pests and as a possible substitute for the traditional chemical used [1,2]. Already, it exists a high number of studies focused on the selection of microorganisms to inhibit and even kill pests, the evaluation of effectiveness against pests, the mechanisms of action, the production systems and the viability $[3,4]$. The production of microorganisms BCA's (Biocontrol Agent) is a core point to gain ground to the chemical pesticides. In the particular case of filamentous fungi, the best way to apply on fields is through conidia because they are cell structures very resistant to hostile conditions of the environment [5]. Filamentous fungi have a long been the subject of research. Indeed, many of them have been used as biopesticides because they are ubiquitous colonizers of their habitats as well as for their secretion capacity for antibiotic metabolites and enzymes [6]. Trichoderma is an important fungus genus used for biological control, these fungi could be a good model for biocontrol (BC) application because of their mechanisms of action: nutrients and space competition, antibiotics production, lytic enzymes production and mycoparasitism [7]. For these aspects, they are considered as one of the most effective BC against several pests [7, 8]. The biomass production systems using solid substrates have shown excellent yields for the production of fungal conidia [9]. Solid-statefermentation (SSF) is a microbial culture process that generally occurs on solid material in the absence of free water. This type of fermentation stimulates the living conditions of fungal strains and is a model for the study of physiology or metabolism of microorganisms such as enzyme production [10]. SSF allows the valorization of agroindustrial byproducts having an impact on the worldwide ecology $[11,12]$. This process has the potential to produce high value-added products such as antibiotics, pigments, aromas like 6-pentylalpha-pyrone (6-PP) and enzymes of industrial interest like cellulases, lipase, chitinase, amylase, etc., [13, 14]. 6-PP is a secondary metabolites showing interesting fungicidal properties and coconut like aroma.

Several reports have been published on the topic of conidia production under SSF to evaluate the effect of water stress on sporulation. Indeed, fungal conidia is a resistant propagule, able to tolerate critical environmental conditions and having a long self-life [5, 15]. On the present study, the application of forced aeration through a solid-state fermentation using three Trichoderma asperellum strains is evaluated to produce 6-PP, conidia and essential enzymes. A mix of agroindustrial byproducts like vine shoots, jatropha, potatoes flour, olive pomace and olive oil is used as substrate, which offer economic advantages in the fermentation process. Indeed, vine shoots is the most abundant byproduct in viticulture industry, generated during the pruning season.

\section{Materials and Methods}

\section{Microorganisms and Culture Conditions}

The strains of Trichoderma: T. asperellum TV104, T. asperellum QT22046 and T. asperellum TF1, from the IRD/ IMBE fungi collection were used in the study. The fungal strains were conserved in sterilized PDA, incubated during 5 days at $30{ }^{\circ} \mathrm{C}$ and conserved at $4{ }^{\circ} \mathrm{C}$.

\section{Solid State Fermentation (SSF)}

SSF were carried out on solid medium composed by a mix of vine shoots, potatoes flour, jatropha, olive pomace and olive oil. The proportion of substrates was 30-20-20-20-10\% (on dry weight basis) and the carbon: nitrogen ratio $(\mathrm{C} / \mathrm{N})$ was 37. Medium composition and proportion were selected after a screening and optimization of 6-PP, lytic enzymes and conidia production from SSF using Experimental design by Trichoderma strains [16].

Culture media were sterilized at $121{ }^{\circ} \mathrm{C}$ for $30 \mathrm{~min}$ and subsequently inoculated with a concentrated conidia suspension to reach a value of $2 \times 10^{7}$ conidia $^{-1}$ dry matter (DM). Initial $\mathrm{pH}$ and moisture contents were 6 and 55\% respectively. Cultures were carried out at $29{ }^{\circ} \mathrm{C}$ in $250 \mathrm{ml}$ Raimbault glass columns (bioreactor with a forced aeration) and in $250 \mathrm{ml}$ flasks (bioreactor without forced aeration) packed with $40 \mathrm{~g}$ of solid (DM). For column, the fermentation was done with the application of humid air during all the process 
and the initial aeration rate was $60 \mathrm{ml} \mathrm{min}^{-1} \mathrm{~g} \mathrm{DM}^{-1}$ of saturated humid air. Flasks are not hermetically closed that some oxygen could flow by diffusion.

\section{Extraction of 6-PP}

Volatiles compounds were recovered by soxhlet extraction system from solid fermented material using pure heptane (99.7\% , Sigma Aldrich, USA). Samples (10 g of the fermented material) were co-distilled at $60{ }^{\circ} \mathrm{C}$ with $100 \mathrm{ml}$ of heptane during $4 \mathrm{~h}$.

\section{Quantitative Analysis of Secondary Metabolites}

6-PP analysis was performed with a gas chromatograph 7890A (GC) (Agilent Technology, USA) equipped with a split/splitless injector $\left(\mathrm{T}=260^{\circ} \mathrm{C}\right)$ and a flame ionization detector $\left(\mathrm{T}=260^{\circ} \mathrm{C}\right)$. Aroma constituents were separated on a Supelcowax capillary column (internal diameter: $0.25 \mathrm{~mm}$, length: $60 \mathrm{~m}$, film thickness: $0.25 \mu \mathrm{m}$ ). The carrier gas was

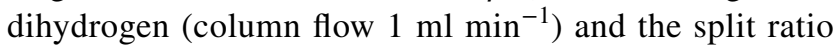
was $2: 1$. The oven temperature was set as follow: $30 \mathrm{~min}$ at $180{ }^{\circ} \mathrm{C}$, from 180 to $230{ }^{\circ} \mathrm{C}$ at $10{ }^{\circ} \mathrm{C} \mathrm{min}{ }^{-1}, 30 \mathrm{~min}$ at $230^{\circ} \mathrm{C}$. Quantitative analysis of 6-PP was carried out using the internal calibration method, with $\gamma$-undecanolactone (99\%, Aldrich) as internal standard.

For 6-PP analysis, a repeatability analysis was performed; the treatment (extraction and analysis by GC) has been repeated 10 times already. The generation and the data treatment were performed using the Microsoft Excel 2016.

\section{Conidia Production Determination}

Conidia counting was done by mixing $1 \mathrm{~g}$ of fermented material with $100 \mathrm{ml}$ of distilled water containing tween $80(0.01 \%)$ in an Erlenmeyer flask, after that the suspension conidia were counted using a hemocytometer and a microscope [17]. Each counting was done in triplicates. The results are exprimed as $\%$ conidia $=$ mean \pm standard deviation.

\section{Enzyme Assays}

Fermented material $(1 \mathrm{~g})$ was mixed with $20 \mathrm{ml}$ of distilled water, the suspension was homogenized using an Ultra-turax ${ }^{\circledR}{ }^{\circledR}$ for $1 \mathrm{~min}$. $1 \mathrm{ml}$ of liquid extracts was used to determine enzymes activities. Amylase activity was measured using soluble starch (1\%) in phosphate buffer $(0.1 \mathrm{M}, \mathrm{pH} 7.0)$ at $50{ }^{\circ} \mathrm{C}$ for $10 \mathrm{~min}$ [18]. Cellulases activities were determined using sodium carboxymethyl cellulose $(1 \%)$ in sodium citrate buffer $(50 \mathrm{mM}, \mathrm{pH} 4.8)$ at $50{ }^{\circ} \mathrm{C}$ for $30 \mathrm{~min}$, in according with De la Cruz-Quiroz et al. [19].
For the two enzymes determinations mentioned above, the corresponding activities were stopped with ice for $5 \mathrm{~min}$. Sugar concentration was determined after each enzyme reaction according to the amount of resulting reducing sugar using 3,5-dinitro salicylic acid (DNS) following the assay method described by Miller [20]. Each treatment was done in triplicates and monitored kinetically. The results are exprimed as activities $=$ mean \pm standard deviation An enzyme activity (U) was defined as the amount of enzyme that catalyzes the release of $1 \mu \mathrm{mol}$ of glucose per minute. Lipase activities were determined using $0.5 \mathrm{ml}$ of p-nitrophenyl octanoate $(25 \mathrm{mM})$ in phosphate buffer $(25 \mathrm{mM}, \mathrm{pH}$ 7.0) at $30{ }^{\circ} \mathrm{C}$ for $30 \mathrm{~min}$ [21]. Lipase activities (U) were defined as the amount of enzyme required to release $1 \mu \mathrm{mol}$ of p-nitrophenol per minute.

\section{Scanning Electronic Microscopy (SEM)}

SEM observations present a good way to study the structure of the solid medium and the conidia adhesion to its surface. Samples inoculated with $T$. asperellum TF1 were immediately fixed in cacodylate-buffered with $2.5 \%$ glutaraldehyde (pH 7.4) for $4 \mathrm{~h}$ at $4{ }^{\circ} \mathrm{C}$, post-fixed with $1 \%$ osmium for $1 \mathrm{~h}$ at $4{ }^{\circ} \mathrm{C}$, and dehydrated in ethanol series. Critical point dried specimens were coated with gold palladium and viewed by using a Philipps XL-30 scanning electron microscope.

\section{Results and Discussion}

\section{Determination of the Enzyme Activities During the Solid State Fermentation Without Forced Aeration}

The highest value of cellulases activities was shown by $T$. asperellum QT22046 at $46 \mathrm{~h}\left(37.1 \pm 0.7 \mathrm{U} \mathrm{g}^{-1}\right)$, followed by T. asperellum $\mathrm{TF} 1$ and T. asperellum TV104 with $10.3 \pm 0.2$ and $6.9 \pm 0.1 \mathrm{U} \mathrm{g}^{-1}$, respectively (Fig. 1a, b, c). T. asperellum QT22046 also resulted in important amylase activity $\left(48.1 \pm 0.9 \mathrm{U} \mathrm{g}^{-1}\right.$ at $\left.30 \mathrm{~h}\right)$ followed by $T$. asperellum $\mathrm{TF} 1$ and T. asperellum TV 104 with $11.9 \pm 0.2 \mathrm{U} \mathrm{g}^{-1}$ at $46 \mathrm{~h}$ and $6.7 \pm 0.1 \mathrm{U} \mathrm{g}^{-1}$ at $56 \mathrm{~h}$, respectively (Fig. $1 \mathrm{a}, \mathrm{b}, \mathrm{c}$ ). There was a gradual increase in the lipase activity by all the strains tested. T. asperellum TF1 and T. asperellum TV104 showed the highest lipase activity $\left(25.5 \pm 0.3\right.$ and $23.6 \pm 0.2 \mathrm{U} \mathrm{g}^{-1}$ at $46 \mathrm{~h}$, respectively), followed by $T$. asperellum QT22046 with $15.2 \pm 0.1 \mathrm{U} \mathrm{g}^{-1}$. The maximum lipase activity were shown by $T$. asperellum TF1 with a value of $25.5 \pm 0.3 \mathrm{U} \mathrm{g}^{-1}$ at $46 \mathrm{~h}$ (Fig. 1b). 
T.asperellum TV104

amylase $\mathbf{a}$ cellulases alipase

(a)

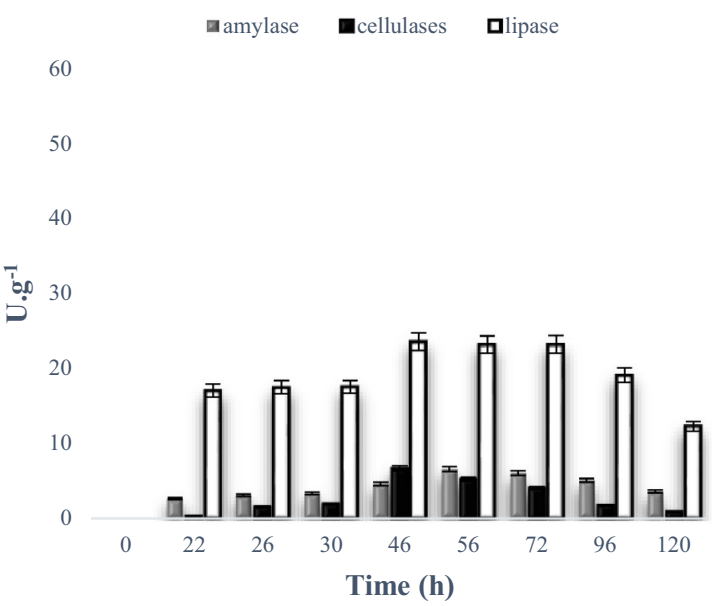

T.asperellum TF1

amylase $\mathbf{m}$ cellulases $\mathbf{D}$ lipase

(b)

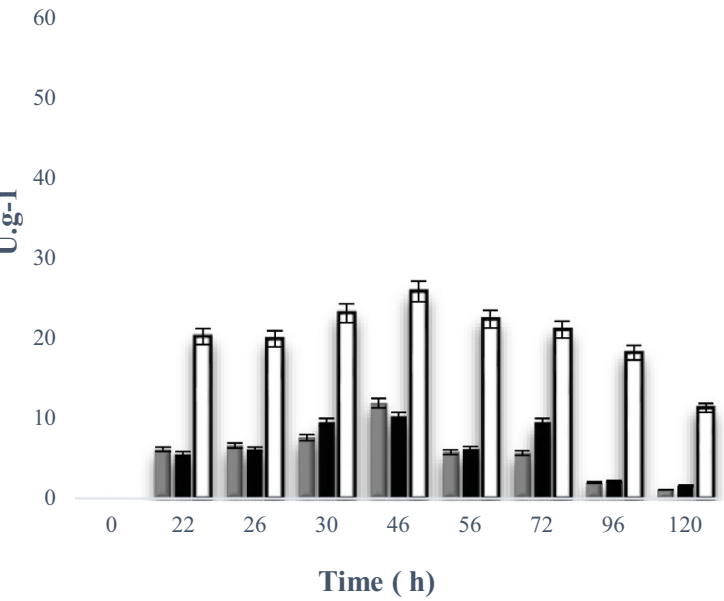

T.asperellum QT22046

amylase acellulases alipase

60

$\stackrel{5}{\triangleright}^{50} 40$

(c)

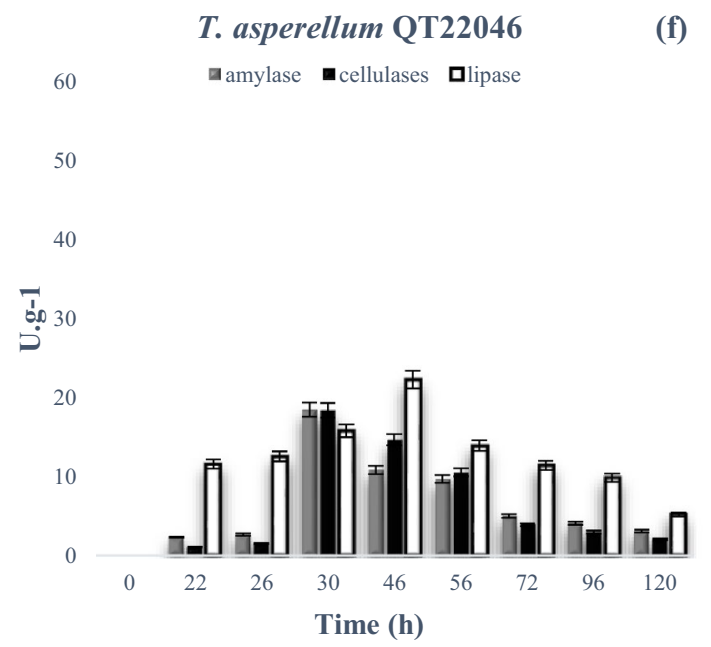

T.asperellum TV104

(d)

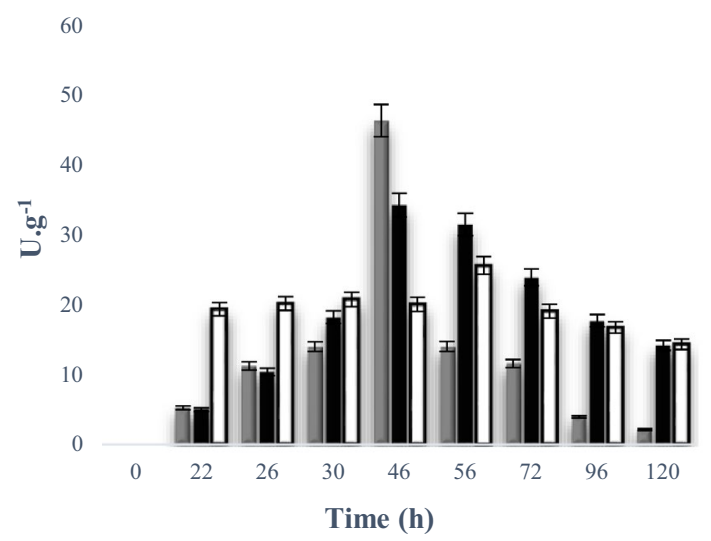

$$
\text { T. asperellum TF1 }
$$

(e)

$$
\text { aamylase - cellulases 口lipase }
$$

$$
\begin{aligned}
& 60 \\
& 50
\end{aligned}
$$

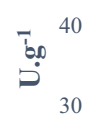

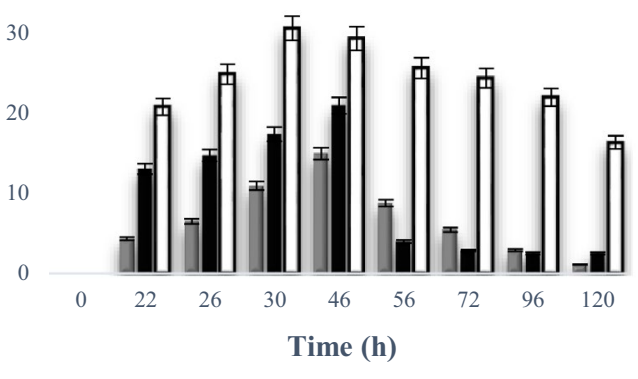

(f) 


\section{Determination of the Enzyme Activities During the Forced Aerated Solid-State Fermentation}

For cellulases activities, aeration induced an increase of production for T. asperellum TV104 and T. asperellum TF1, and a decrease for T. asperellum QT22046. T. asperellum TF1 showed a significant difference in both systems; $20.9 \pm 0.2$ $\mathrm{U} \mathrm{g}^{-1}$ with forced aeration and $10.3 \pm 0.2 \mathrm{U} \mathrm{g}^{-1}$ without forced aeration at $46 \mathrm{~h}$ (Fig. 1b, e). For amylase production, the strains T. asperellum TV104 and T. asperellum TF1 were affected positively by aeration showing activity values of $46.3 \pm 0.7 \mathrm{U} \mathrm{g}^{-1}$ and $14.9 \pm 0.1 \mathrm{U} \mathrm{g}^{-1}$ at $46 \mathrm{~h}$ respectively. For the strain T. asperellum QT22046 the application of air did not show an improvement on amylase production, it was significantly decreased with $47.3 \pm 0.4 \mathrm{U} \mathrm{g}^{-1}$ obtained without aeration and $10.9 \pm 0.2 \mathrm{U} \mathrm{g}^{-1}$ in aerated system at $46 \mathrm{~h}$ (Fig. 1f). Comparing both production systems revealed a significant decrease on lipase, cellulases and amylase activities by T. asperellum QT22046. However, the strains T. asperellum TF1 and T. asperellum TV104 showed best enzyme activities with forced aeration.

\section{Comparison of the Performances of the Forced Aeration for 6-PP Production During the Solid-State-Fermentation}

The maximum of 6-PP production for T. asperellum TV104 and T. asperellum TF1 was achieved between

Table 1 Production of 6-PP during T. asperellum strains cultures with and without forced aeration $(\alpha=5 \%)$

\begin{tabular}{|c|c|c|c|}
\hline Fungal strains & $\begin{array}{l}\text { Culture } \\
\text { time }(\mathrm{h})\end{array}$ & $\begin{array}{l}\text { Without } \\
\text { forced aeration } \\
\left(\mathrm{mg} \mathrm{g} \mathrm{DM}^{-1}\right)\end{array}$ & $\begin{array}{l}\text { With forced } \\
\text { aeration } \\
\mathrm{mg} \mathrm{g} \mathrm{DM}^{-1}\end{array}$ \\
\hline \multirow{6}{*}{$\begin{array}{l}\text { T. asperel- } \\
\text { lumTV104 }\end{array}$} & 30 & $0.14 \pm 0.01$ & 0 \\
\hline & 46 & $1.39 \pm 0.07$ & $2.02 \pm 0.10$ \\
\hline & 56 & $1.12 \pm 0.06$ & $2.87 \pm 0.14$ \\
\hline & 72 & $1.05 \pm 0.05$ & $3.06 \pm 0.15$ \\
\hline & 96 & $0.33 \pm 0.02$ & $1.41 \pm 0.07$ \\
\hline & 120 & $0.34 \pm 0.02$ & $0.09 \pm 0.01$ \\
\hline \multirow[t]{6}{*}{ T. asperellum TF1 } & 30 & 0 & 0 \\
\hline & 46 & $0.58 \pm 0.03$ & $0.04 \pm 0.01$ \\
\hline & 56 & $0.59 \pm 0.03$ & $0.43 \pm 0.02$ \\
\hline & 72 & $0.59 \pm 0.03$ & $1.71 \pm 0.09$ \\
\hline & 96 & $1.69 \pm 0.08$ & $1.09 \pm 0.05$ \\
\hline & 120 & $1.38 \pm 0.07$ & $0.32 \pm 0.02$ \\
\hline \multirow{6}{*}{$\begin{array}{l}\text { T. asperellum } \\
\text { QT22046 }\end{array}$} & 30 & 0 & $0.65 \pm 0.03$ \\
\hline & 46 & $0.03 \pm 0.01$ & $0.66 \pm 0.03$ \\
\hline & 56 & $0.07 \pm 0.01$ & $0.73 \pm 0.04$ \\
\hline & 72 & $0.04 \pm 0.01$ & $0.29 \pm 0.02$ \\
\hline & 96 & $0.03 \pm 0.01$ & $0.24 \pm 0.01$ \\
\hline & 120 & $0.03 \pm 0.01$ & $0.20 \pm 0.01$ \\
\hline
\end{tabular}

46 and $72 \mathrm{~h}$ of fermentation when forced aeration has been applied. T. asperellum TV104 resulted in a production of $3.06 \pm 0.15 \mathrm{mg} \mathrm{g} \mathrm{DM}^{-1}$ (forced aerated) and $1.05 \pm 0.05 \mathrm{mg} \mathrm{g} \mathrm{DM}^{-1}$ (not forced aerated). After $96 \mathrm{~h}$ of culture, the 6-PP production decreased with important changes (Table 1).

T. asperellum TV104 and T. asperellum TF1 showed a very similar pattern of 6-PP production in forced aeration system. The kinetic profile showed that the highest coconut aroma concentration was reached at $72 \mathrm{~h}$ of fermentation (forced aerated) and at $96 \mathrm{~h}$ of culture (not forced aerated) for $T$. asperellum TF1. This strain showed values of $1.71 \pm 0.09 \mathrm{mg} \mathrm{g} \mathrm{DM}^{-1}$ (forced aerated) at $72 \mathrm{~h}$ and $1.69 \pm 0.08 \mathrm{mg} \mathrm{g} \mathrm{DM}^{-1}$ (not forced aerated) at $96 \mathrm{~h}$.

T. asperellum QT22046 was affected positively by aeration for 6-PP production. The maximum 6-PP production was showed at $56 \mathrm{~h}$ of culture for the both conditions with significant difference. When the system was aerated, the best values of 6-PP was $0.73 \pm 0.04 \mathrm{mg} \mathrm{g} \mathrm{DM}^{-1} \mathrm{~h}$. However, the system without forced aeration showed a value of $0.07 \pm 0.01 \mathrm{mg} \mathrm{g} \mathrm{DM}^{-1}$.

\section{Forced Aeration Influence on the Production of Conidia}

Conidia production of $T$. asperellum cultivated in Raimbault columns (with forced aeration) and flasks cultures, is shown in Fig. 2. Highest concentration of conidia is reached in treatments with forced aeration $\left(2.23 \pm 0.07 \times 10^{9}\right.$ conidia $\mathrm{g} \mathrm{DM}^{-1}$ ) at $120 \mathrm{~h}$ by T. asperellum TF1 (Fig. 2a), followed closely by $T$. asperellum QT22046 $\left(0.44 \pm 0.01 \times 10^{9}\right.$ conidia $\mathrm{g} \mathrm{DM}^{-1}$ ) also at $120 \mathrm{~h}$.

For those two strains, a significant difference was observed on the conidia production which was positively affected by forced aeration. However, conidia production by $T$. asperellum TV104 was not affected by the presence or the absence of forced aeration (Fig. 2a, b, c). The best index of conidia was showed on $120 \mathrm{~h}$ of culture time without significant difference $\left(0.13 \pm 0.01 \times 10^{9}\right.$ conidia $\left.\mathrm{g} \mathrm{DM}^{-1}\right)$ with forced aeration and $0.11 \pm 0.01 \times 10^{9}$ conidia $\mathrm{g} \mathrm{DM}^{-1}$ without forced aeration).

In addition, the maximum enzymes activities and 6-PP production were achieved before $120 \mathrm{~h}$, however conidia production is still increasing at $120 \mathrm{~h}$, we preferred to stop the kinetically study in order to not lose the other metabolites obtained at the beginning of the culture.

\section{SEM Structure of the Vine Shoot}

Figure 3 shows the morphology of the vine shoots before inoculation (Fig. 3a) and the invasion of the ligneous part of the material by conidia immediately after inoculation with T. asperellum TF1. The inoculated vine shoots tubule is a 
Fig. 2 Kinetics of conidia production by three Trichoderma asperellum TF1, QT22046 and TV104 grown under solidstate fermentation with forced aeration (a) and without forced aeration (b)
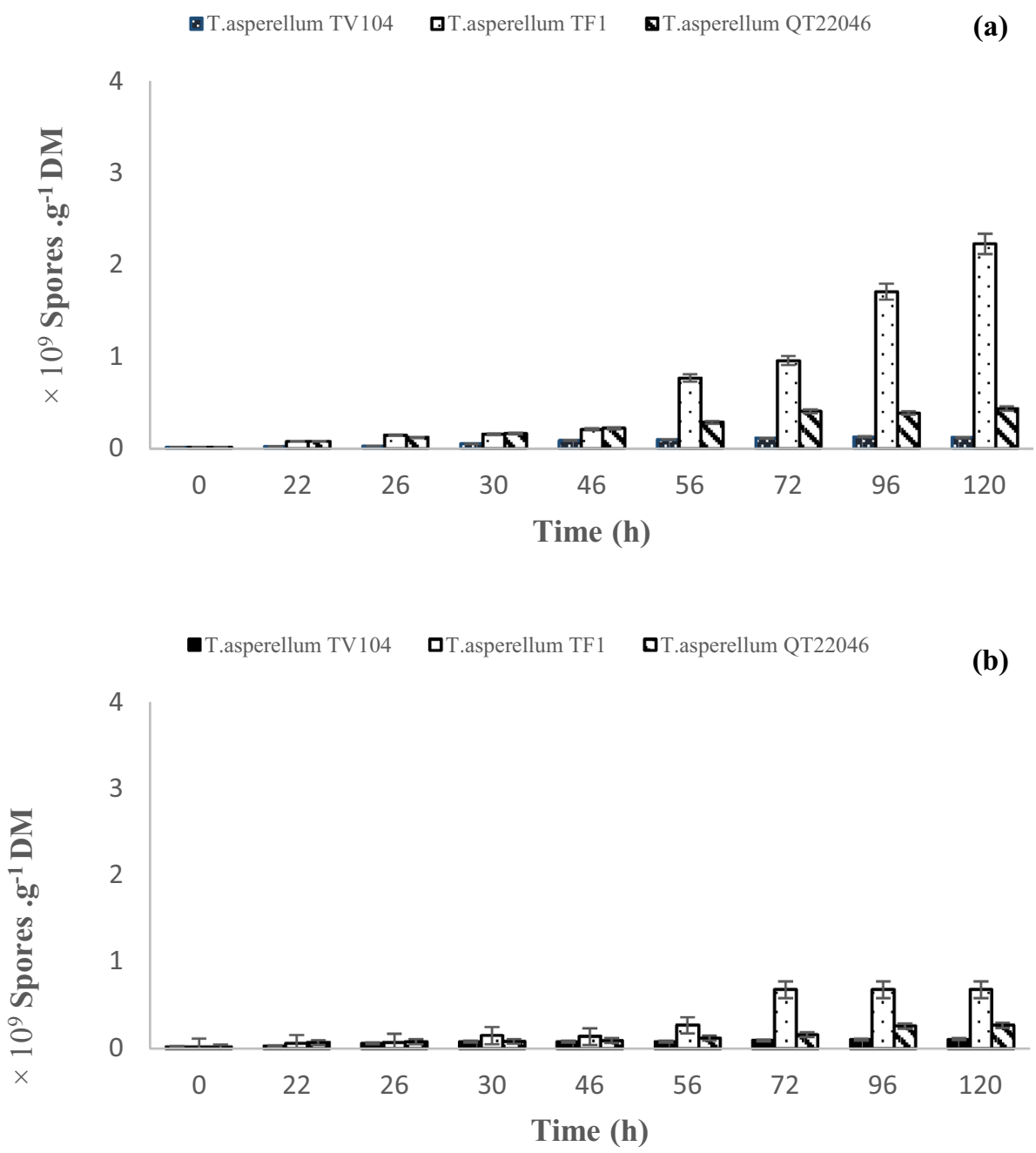

honey-comb like structure, with fibers, grooves and pores (Fig. 3b). The external face showed a longitudinal groove which is like an open drainpipe or a guiding ridge that may help germination and mycelium growing (Fig. 3b, inset). The tick outer surface of the stem tissue corresponds to the cortex following by vascular tissue, named phloem (Fig. 3c).

\section{Discussion}

In this study, an evaluation of the effect of aeration on the production of volatile metabolites, lytic enzymes and conidia by $T$. asperellum strains in SSF is proposed. Conventionally SSF is done using tray bioreactors, however, this kind of bioreactors implies the difficulties of aeration and heat removal, which can be attended by the use of Raimbault columns as bioreactors [22]. The use of glass columns allows the application of controlled forced aeration to remove both $\mathrm{CO}_{2}$ and the metabolic heat generated during the fermentation. It also provides better oxygen diffusion, thus improving the fungal growth and the production of metabolites. Generally, substrates for SSF are agricultural byproducts or agroindustrial subproducts, which offer advantages in this fermentation process [23]. In SSF, the culture medium has to be considered following two aspects: as substrate, it has to efficiently provide microbial nutritional needs, and as support of culture, it has to possess favorable physical properties having consequence on water availability and allowing initial conidial anchorage, mycelial elongation in space and mass and heat transfers to occur over time [24]. A mix of substrates was studied in the present study, which was used by the fungi as a source of nutrients. It is well known that vine shoot plays an important role because its porosity allowing good water absorption, indispensable to carried out the microbial metabolism (a basic macromolecular structure of cellulose, lignocellulose). In addition, potatoes flour, jatropha, olive pomace and olive oil supply the carbon and nitrogen source to induce the synthesis of 6-PP and a group of enzymes [25]. The present study demonstrated for the first time the ability of $T$. asperellum strains to 


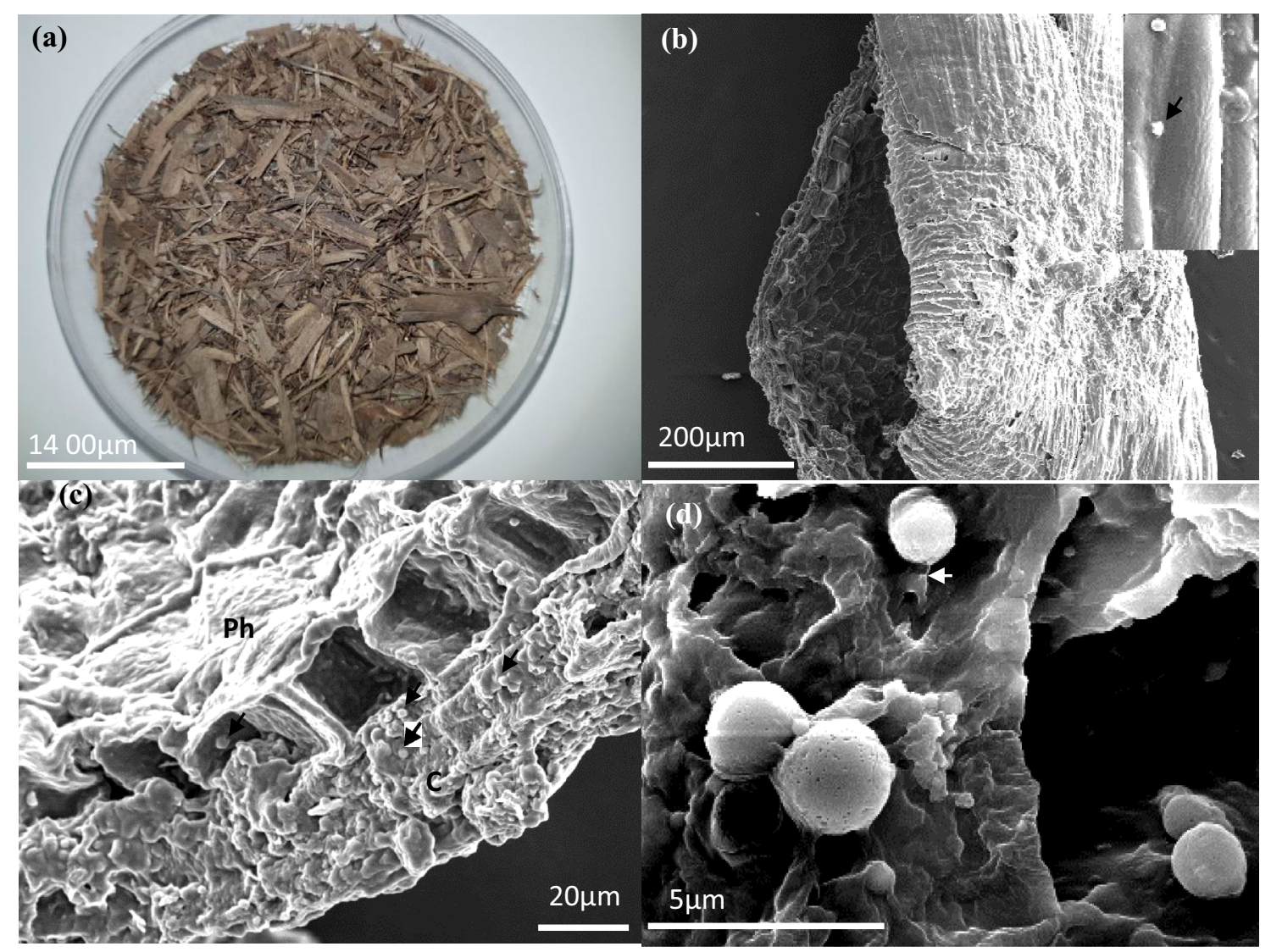

Fig. 3 SEM Structure of inoculated vine shoots. a Structure of vine shoots fragments observed under light microscopy. b Honey-comb like structure of vine shoot, inset: details of the inoculated groove with T. asperellum TF1 (SEM images). c Colonization of spores

produce 6-PP, coconut like aroma, from vine shoot according the parameters established by SSF.

Forced aeration during SSF is particularly important for T. asperellum TV104 as it may affect fungal growth, lytic enzymes and 6-PP production. The biosynthesis of significant amount of 6-PP was observed after $72 \mathrm{~h}$ of culture during the application of forced aeration.

Ladeira et al. [26] reported a maximum 6-PP yield of $2.54 \mu \mathrm{g} \mathrm{g} \mathrm{DM}{ }^{-1}$ by a Trichoderma harzianum 4040 after 7 days of SSF on sugarcane bagasse impregnated to $75 \%$ humidity, with a nutrient solution. 6-PP production started at day 3. Results reported in the present study indicated that T. asperellum TV104 cultured on a mix of substrate like vine shoots, potatoes flour, jatropha, olive pomace and olive oil (owing a $\mathrm{C} / \mathrm{N}$ ratio of 37) produced $3.06 \mathrm{mg} 6-\mathrm{PP} \mathrm{g} \mathrm{DM}^{-1}$ after 3 days of SSF and the 6-PP production started at $46 \mathrm{~h}$.

Oda et al. [27] obtained higher yields in 6-PP synthesis

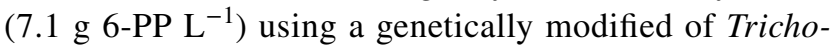
derma, however, it is not possible to do an effective comparison between the results obtained by those authors and ours because they used a liquid medium with a different (black arrow) over the surface of the tick cortex (C) and phloem $(\mathrm{Ph})$. d Adhesion to the surface substrate by a gelatinous matrix (with arrow) secreted by the conidia

nutrient compound impregnate system. In addition, the performances of SSF with and without forced aeration were compared (Table 1) by 6-PP production for T. asperellum strains. A significant difference on 6-PP production was observed only during the application of forced aeration for T. asperellum TV104. The aroma production decreased on the fourth day of culture for the two systems. These results agree with those of Rocha-Valadez et al. [28] who reported the decrease of 6-PP production after $120 \mathrm{~h}$ of culture by $T$. harzianum IMI206040 using a stirred tank fermentations. In addition, the decrease of 6-PP production was reported in liquid medium fermentation but not observed in the solidstate fermentation realized by Sarhy-Bagnon et al. [29]. These authors explained that the inhibitory effect of 6-PP appeared to be responsible for low concentrations obtained in liquid medium.

It was observed a positive effect of the forced aeration on the production of enzymes (cellulases, amylase and lipase) produced at high titers by T. asperellum TV104 and T. asperellum TF1 (Fig. 1). A great difference was observed whether or not a forced aeration was applied in 
the Raimbault columns with regards to the cellulases and amylase. In aerated system, the maximum of amylase and cellulase were $34.23 \pm 0.43 \mathrm{U} \mathrm{g}^{-1}$ and $46.23 \pm 0.63 \mathrm{U} \mathrm{g}^{-1}$ respectively obtained after $46 \mathrm{~h}$, but the values of lipase were maintained with any important modification by the application of air for T. asperellum TF1 and T. asperellum TV104. Oliveira et al. [30] reported important lipase activity $\left(223 \pm 5 \mathrm{U} \mathrm{g}^{-1}\right)$ applying an aeration rate of $2 \mathrm{ml} \mathrm{min}^{-1} \mathrm{~g}^{-1}$ using wheat bran with $10 \%$ of olive oil as substrate on SSF by Aspergillus ibericus.

On the other hand, the results show that SSF system without forced aeration is better for the production of all enzyme activities tested for T. asperellum QT22046. These results agree with those of De la Cruz-Quiroz et al. [19] who reported that lipase and cellulases are well produced in both systems by Trichoderma strains without forced aeration. In addition the difference between this work and that described by De la Cruz-Quiroz et al. [19] is that those authors used other medium composed by sugarcane bagasse, wheat bran, chitin, potatoes flour olive oil as substrate, other Trichoderma species and they were not interested to produce 6-PP.

The values of the enzymes obtained in this study were highly variables suggesting that the enzyme activities were more related to the intrinsic capabilities of the present fungal strains than the effect of the air. The production of lytic enzymes is a currently topic that is investigated evaluating several ways, including reactors, substrates, kind of enzymes, fungal strains, etc. [31, 32].

On a solid culture medium, it has been demonstrated a relationship between the high sporulation yields with the carbon and nitrogen sources supplied. Those sources were proportioned with a mix of substrates mentioned before, which contain amounts of nutrients like sugars, amino acids, fats, fiber, and minerals. These substrates allowed an elevated conidia production which is in agreement with Onilude et al. [33]. A very marked pattern was observed on the conidia production because forced aeration show an increase in the production for T. asperellum $\mathrm{TF} 1$ and T.asperellum QT22046. Is does mean that the production of conidia from T. asperellum is more related to forced aeration process which possibly was stressing the culture conditions and causing an increase in the concentration of conidia. These results confirm those previously obtained by Motta and Santana, [34] who tested the fungal sporulation by Trichoderma reesei using fruit bunches as substrate evaluating an aeration rate of $16.6 \mathrm{ml} \mathrm{min}^{-1} \mathrm{~g}^{-1}$. These authors indicated that the forced aeration has a high influence on the stimulation of fungal sporulation $\left(4.41 \times 10^{9}\right.$ conidia $\mathrm{g} \mathrm{DM}^{-1}$ at $120 \mathrm{~h}$ of culture). However, De la Cruz-Quiroz et al., [19, 35] observed the opposite phenomenon. They mentioned that the application of forced aeration in the process did not show any increase in the spore production for any of the six Trichoderma strains tested.
In SSF, the growth of T. asperellum TF1 on the ligneous part of vine shoots observed by scanning electron microscopy showed that the invasion of the strain on the solid support was superficial. The conidia of T. asperellum TF1 cultivated on solid support were in contact with heterogeneous medium compared to the cultivation in liquid medium. Sarhy-Bagnon et al. [29] described the end-product inhibition phenomena could be reduced in SSF compared to liquid cultivation and the aerial mycelium in SSF was only locally in contact with the products and the substrates.

\section{Conclusions}

Under the present culture conditions, the production of Trichoderma asperellum metabolites in solid medium with vine shoot as substrate is possible and offers very interesting quantitative and qualitative advantages. The application of forced aeration on SSF system allows producing high amount of 6-PP by all T. asperellum strains tested in this study. The cellulase, amylase and lipase activities could be produced by T. asperellum TV104 and T. asperellum TF1 in important concentrations on SSF with forced aeration. SSF system without aeration is useful to obtain the best titers of cellulases, amylases and lipases by T. asperellum QT22046. The application of air into SSF system allows a stabilized system to produce a high yield of conidia from Trichoderma, the results obtained on the process with forced aeration show a high sporulation by $T$. asperellum $\mathrm{TF} 1$ and $T$. asperellum QT22046. Conidia could be produced by $T$. asperellum TV104 with no significant difference concentration on SSF with and without forced aeration.

Acknowledgements Authors thank EURASMUS + mobility for the financial support during the stay in France. Hamrouni also thank Tunisian Republic “Tunis El Manar University”, Institut de Recherche pour le Development (IRD), the Institut Méditerranén de Biodiversité et d'Ecologie Marine et Continentale (IMBE), and the planning direction office of Aix Marseille University for the support and technical facilities.

Open Access This article is distributed under the terms of the Creative Commons Attribution 4.0 International License (http://creativeco mmons.org/licenses/by/4.0/), which permits unrestricted use, distribution, and reproduction in any medium, provided you give appropriate credit to the original author(s) and the source, provide a link to the Creative Commons license, and indicate if changes were made.

\section{References}

1. Miranda-Hernández, F., Garza-López, P.M., Loera, O.: Cellular signaling in cross protection: an alternative to improve mycopesticides. Biol. Control 103, 196-203 (2016) 
2. Tranier, M.S., Pognant-Gros, J., Quiroz, R.D.L.C., González, C.N.A., Mateille, T., Roussos, S.: Commercial biological control agents targeted against plant-parasitic root-knot nematodes. Braz. Arch. Biol. Technol. 57, 831-841 (2014)

3. Innocenti, G., Roberti, R., Piattoni, F.: Biocontrol ability of Trichoderma harzianum strain T22 against Fusarium wilt disease on water-stressed lettuce plants. Biol. Control 60, 573-581 (2015)

4. Keswani, C., Bisen, K., Singh, V., Sarma, B.K., Singh, H.B.: Formulation technology of biocontrol agents: present status and future prospects. In: Arora, N.K., Mehnaz, S., Balestrini, R. (eds.) Bioformulations: For Sustainable Agriculture, pp. 35-52. Springer, New Delhi (2016)

5. De la Cruz Quiroz, R., Roussos, S., Hernández, D., Rodríguez, R., Castillo, F., Aguilar, C.N.: Challenges and opportunities of the bio-pesticides production by solid-state fermentation: filamentous fungi as a model. Crit. Rev. Biotechnol. 35, 326-333 (2015)

6. Rodríguez-Fernández, D.E., Rodríguez-León, J.A., De Carvalho, J.C., Karp, S.G., Sturm, W., Parada, J.L., Soccol, C.R.: Influence of air flow intensity on phytase production by solid-state fermentation. Biores. Technol. 118, 603-606 (2012)

7. Junaid, J.M., Dar, N.A., Bhat, T.A., Bhat, A.H., Bhat, M.A.: Commercial biocontrol agents and their mechanism of action in the management of plant pathogens. Int. J. Mod. Plant Anim. Sci. 1, 39-57 (2013)

8. Zachow, C., Berg, C., Müller, H., Monk, J., Berg, G.: Endemic plants harbour specific Trichoderma communities with an exceptional potential for biocontrol of phytopathogens. J. Biotechnol. 235, 162-170 (2016)

9. Mascarin, G.M., Jaronski, S.T.: The production and uses of Beauveria bassiana as a microbial insecticide. World J. Microbiol. Biotechnol. 32, 177 (2016)

10. Holker, U., Lenz, J.: Solid-state fermentation-are there any biotechnological advantages? Curr. Opin. Microbiol. 8, 301-306 (2005)

11. Viniegra González, G., Roussos, S., Lonsane, B.K., Raimbault, M.: Advances in Solid State Fermentation, p. 631. Kluwer Academic Publishers, Dordrecht (1997)

12. Sharma, A., Tewari, R., Rana, S.S., Soni, R., Soni, S.K.: Cellulases: classification, methods of determination and industrial applications. Appl. Biochem. Biotechnol. 179, 1346-1380 (2016)

13. Sarhy-Bagnon, V.: Production de 6-pentyl-alpha-pyrone par Trichoderma harzianum cultivé sur support solide. Thèse de doctorat, Université de Montpellier (1998)

14. Gutierrez-Sanchez, G., Roussos, S., Augur, C.: Effect of caffeine concentration on biomass production, caffeine degradation, and morphology of Aspergillus tamarii. Folia Microbiol. 58, 195-200 (2013)

15. Loera-Corral, O., Porcayo-Loza, J., Montesinos-Matias, R., Favela-Torres, E.: Production of conidia by the fungus Metarhizium anisopliae using solid-state fermentation. In: Glare, T.R., Moran-Diez, M.E. (eds.) Microbial-Based Biopesticides. Springer, Berlin, pp. 61-69 (2016)

16. Hamrouni, R., Claeys-Bruno, M., Molinet, J., Masmoudi, A., Roussos, S., Dupuy, N.: Challenges of enzymes, conidia and 6-pentyl-alpha-pyrone production from solid-state-fermentation of agroindustrial wastes using experimental design and T. asperellum strains. Submitted for Publication in Waste and Biomass valorization. WAVE-D-19-00267 (2019)

17. Soccol, C.R.: Physiology and metabolism of Rhizopus in solid and submerged culture in relation to the degradation of raw starch and the production of $\mathrm{L}(+)$-lactic acid. $\mathrm{PhD}$ thesis. Université de Compiègne. France (In French) (1992)
18. Singh, S., Singh, S., Bali, V., Sharma, L., Mangla, J.: Production of fungal amylases using cheap, readily available agriresidues, for potential application in textile industry. Biomed. Res. Int. (2014). https://doi.org/10.1155/2014/215748

19. De la Cruz-Quiroz, R., Robledo-Padilla, F., Aguilar, C.N., Roussos, S.: Forced aeration influence on the production of spores by Trichoderma strains. Waste Biomass Valoriz. 8, 2263-2270 (2017)

20. Miller, G.L.: Use of dinitrosalicylic acid reagent for determination of reducing sugar. Anal. Chem. 31, 426-428 (1959)

21. Lopes, D.B., Fraga, L.P., Fleuri, L.F., Macedo, G.A.: Lipase and esterase: to what extent can this classification be applied accurately? Food Sci. Technol. 31, 603-613 (2011)

22. Raimbault, M., Alazard, D.: Culture method to study fungal growth in solid fermentation. Eur. J. Appl. Microbiol. Biotechnol. 9, 199-209 (1980)

23. Pandey, A., Soccol, C.R., Larroche, C.: Current Developments in Solid-State Fermentation. Springer, Berlin (2008)

24. Pandey, A., Soccol, C.R., Mitchell, D.: New developments in solid state fermentation: I-bioprocesses and products. Process Biochem. 35, 1153-1169 (2000)

25. Shi, Y., Xu, X., Zhu, Y.: Optimization of Verticillium lecanii spore production in solid-state fermentation on sugarcane bagasse. Appl. Microbiol. Biotechnol. 82, 921 (2009)

26. Ladeira, N.C., Peixoto, V.J., Penha, M.P., de Paula Barros, E.B., Leite, S.G.F.: Optimization of 6-pentyl-alpha-pyrone production by solid state fermentation using sugarcane bagasse as residue. BioResources 5, 2297-2306 (2010)

27. Oda, S., Isshiki, K., Ohashi, S.: Production of 6-pentyl-a-pyrone with $T$. atroviride and its mutant a novel extractive liquid-surface immobilization (EXT-LSI) system. Process Biochem. 44(6), 625-630 (2009)

28. Rocha-Valadez, J.A., Estrada, M., Galindo, E., Serrano-Carreón, L.: From shake flasks to stirred fermentors: scale-up of an extractive fermentation process for 6-pentyl- $\alpha$-pyrone production by Trichoderma harzianum using volumetric power input. Process Biochem. 41, 1347-1352 (2006)

29. Sarhy-Bagnon, V., Lozano, P., Saucedo-Castañeda, G., Roussos, S.: Production of 6-pentyl- $\alpha$-pyrone by Trichoderma harzianum in liquid and solid state cultures. Process Biochem. 36, 103-109 (2000)

30. Oliveira, F., Salgado, J.M., Abrunhosa, L., Pérez-Rodríguez, N., Domínguez, J.M., Venâncio, A., Belo, I.: Optimization of lipase production by solid-state fermentation of olive pomace: from flask to laboratory-scale packed-bed bioreactor. Bioprocess Biosyst. Eng. 40(7), 1123-1132 (2017)

31. Viniegra-González, G., Guevara-Gonzalez, R., Torres-Pacheco, I.: New horizons for the production of industrial enzymes by solidstate fermentation. In: Guevara-Gonzalez, R., Torres-Pacheco, I. (eds.) Biosystems Engineering: Biofactories for Food Production in the Century XXI. Springer, Berlin, pp. 319-340 (2014)

32. Chen, L., Yang, X., Raza, W., Luo, J., Zhang, F., Shen, Q.: Solidstate fermentation of agro-industrial wastes to produce bioorganic fertilizer for the biocontrol of Fusarium wilt of cucumber in continuously cropped soil. Biores. Technol. 102, 3900-3910 (2011)

33. Onilude, A.A., Adebayo-Tayo, B.C., Odeniyi, A.O., Banjo, D., Garuba, E.O.: Comparative mycelial and spore yield by Trichoderma viride in batch and fed-batch cultures. Ann. Microbiol. 63, 547-553 (2013)

34. Motta, F.L., Santana, M.H.A.: Solid-state fermentation for humic acids production by a Trichoderma reesei strain using an oil palm empty fruit bunch as the substrate. Appl. Biochem. Biotechnol. 172, 2205-2217 (2014) 
35. De la Cruz-Quiroz, R., Roussos, S., Hernandez-Castillo, D., Rodríguez-Herrera, R., López-López, L.I., Castillo, F., Aguilar, C.N.: Solid state fermentation in a bag bioreactor: effect of corn cob mixed with phytopathogen biomass on spore and cellulase production by Trichoderma asperellum. Ferment. Process. 3, 43-56 (2017)
Publisher's Note Springer Nature remains neutral with regard to jurisdictional claims in published maps and institutional affiliations.

\section{Affiliations}

\section{Rayhane Hamrouni ${ }^{1,3} \cdot$ Josiane Molinet $^{1} \cdot$ Nathalie Dupuy $^{1} \cdot$ Nadira Taieb $^{1} \cdot$ Quentin Carboue $^{1} \cdot$ Ahmed Masmoudi $^{2}$. Sevastianos Roussos ${ }^{1}$}

$\triangle$ Rayhane Hamrouni rayhan.hamrouni@gmail.com

1 Aix Marseille Univ, Avignon Université, CNRS, IRD, IMBE, Marseille, France
2 Univ. Manouba, ISBST, BVBGR-LR11ES31, Biotechpole Sidi Thabet, 2020 Ariana, Tunisia

3 Univ Tunis El Manar, FST, Campus Universitaire, Tunis, Tunisia 